\title{
The Effect of Money Supply on the Volatility of Korean Stock Market
}

\author{
Ki-Hong Choi, Seong-Min Yoon* \\ Department of Economics, Pusan National University, Busan, Korea \\ Email: smyoon@pusan.ac.kr
}

Received 10 April 2015; accepted 13 May 2015; published 14 May 2015

Copyright (C) 2015 by authors and Scientific Research Publishing Inc.

This work is licensed under the Creative Commons Attribution International License (CC BY). http://creativecommons.org/licenses/by/4.0/

\section{(c) (i) Open Access}

\begin{abstract}
We examined the potential relationships between changes in the money supplies of Korea and the United States and volatility of the Korean stock market using the GARCH, GJR-GARCH, and EGARCH models. We did not identify any such relationships, implying that changes in money supply do not influence the flow of information to the market. However, we found that the asymmetric effect of bad news on volatility was higher when contemporaneous changes in Korean and US money supply variables were included in the models. This indicates that changes in money supply did not affect Korean stock volatility directly. Finally, the results based on a variance model indicated that the money supply of the two countries had no effect on the Korean stock market. This formal study suggests that there is no significant forecasting power of past changes in money supply. Although stock returns and volatility are not directly affected by changes in the money supply, the influence of supply on macroeconomic activity should not be disregarded.
\end{abstract}

\section{Keywords}

Stock Volatility, Money Supply, Asymmetry

\section{Introduction}

Financial economists are very interested in whether money supplies affect stock returns, and various studies have established that they do [1]-[3]. Changes in money supply are closely related to fluctuations in stock prices, directly affect the stock market, and indirectly affect the bond market through interest rate adjustments. If an increase in money supply invokes a decrease in real interest rates, investors would expect stock returns to become higher after an increase in the money supply. However, an excessive increase in the money supply might induce inflation, which will affect stock prices negatively. Thus, money supply may increase the volatility of the stock market.

*Corresponding author. 
However, few papers have analyzed the effects of supply changes on stock return volatility. Of those that have, most have analyzed relationships using a VAR model and the Granger causality test.

In the present study, we investigated whether changes in money supply, as a proxy for information flow, can be used to improve predictions of volatility. For this purpose, we examined the relationships between changes in money supply and stock volatility for the domestic economy of Korea. Changes in monetary policy in major countries such as the United States that provide liquidity in the global financial market will have a negative or positive impact on other countries' financial markets through foreign trading. Thus, we also examined relationships between the US money supply and the Korean stock market.

For the empirical analysis, we considered monthly data regarding the money supplies of the United States and Korea and Korean stock returns. We estimated and analyzed the relationships between return volatility and money supply using the GARCH, Glosten-Jagannathan-Runkle GARCH (GJR-GARCH), and exponential GARCH (EGARCH) models.

The remainder of this paper is organized as follows. A literature review is presented in Section 2. Section 3 presents the data and descriptive statistics. Section 4 presents the methodology of the study. The empirical results are discussed in Section 5. Section 6 concludes the paper.

\section{Literature Review}

The potential effects of money supply on markets have long been debated. Some empirical studies have shown that stock returns are affected by changes in the money supply. Homa and Jaffee [4] presented evidence of a significant and systematic relationship: the average price of stocks was positively correlated with the money supply. Hamburner and Kochin [5] concluded that changes in monetary growth had several different effects on the market. They suggested that there was a direct portfolio effect, although it is difficult to completely disentangle this effect from effects that stem from corporate earnings expectations. Thorbecke [6] reported that expansionary policies increased ex-post stock returns, and exposure to monetary policy increased an asset's exante return. Chen [7] found that monetary policy had larger effects on stock returns in a bear market and showed that a contractionary monetary policy resulted in a higher probability of switching to a bear-market regime. Kwon and Shin [8] investigated the relationship between current economic activities and the Korean stock market. They concluded that stock prices were cointegrated with the money supply in a direct, long-term relationship.

In contrast, other empirical studies have reported that past changes in money supply have no significant forecasting power. Rozeff [9] examined stock market efficiency with respect to data on the money supply by testing regression models of stock returns using monetary variables and trading rules based on supply data. The results indicated that there was no meaningful lag in the effects of monetary policy on the stock market, as well as no profitable security trading rules using past values of the money supply. Rogalski and Vinso [10] showed that causality did not appear to go from money supply to stock prices but rather from stock prices to money supply and possibly back again. Alatiqi and Fazel [11] argued against the existence of any relationship. They reported that there was no causal relationship from money supply to stock prices.

\section{Sample Data}

For the empirical analysis of the present study, we used monthly Korean stock market price index data, the Korean money supply (M1, M2, Lf), and the United States money supply (M1, M2, M3). We used data from January 1980 to June 2013. These data were obtained from the Korea Bank and the Board of Governors of the Federal Reserve System. Monthly index returns were calculated in terms of percentage logarithmic change, based on the following formulae:

$$
\begin{aligned}
r_{t} & =\ln \left(P_{t} / P_{t-1}\right) \times 100, \\
S_{t} & =\ln \left(M_{t} / M_{t-1}\right) \times 100 .
\end{aligned}
$$

where $P_{t}$ is the monthly close of the index and $M_{t}$ is each money supply.

\subsection{Descriptive Statistics}

Tables 1-3 summarize the descriptive statistics for stock market returns and money supply. The mean returns 
Table 1. Summary statistics of returns.

\begin{tabular}{rcc}
\hline & Returns \\
Mean & 0.7082 \\
Median & 0.7237 \\
Minimum & 39.3162 \\
Std. Dev. & -29.9747 \\
Skewness & 7.1689 \\
Kurtosis & 0.2143 \\
Jarque-Bera & 6.3010 \\
\hline
\end{tabular}

Notes: Jarque-Bera (J-B) is the test statistic for the null hypothesis of normality in sample returns distribution. Significance levels: ${ }^{* * *} 1 \%$.

Table 2. Summary statistics of change in Koran money supply.

\begin{tabular}{cccc}
\hline & M1 & M2 & Lf \\
Mean & 1.2133 & 1.3221 & 1.1534 \\
Median & 1.2117 & 1.1968 & 1.0489 \\
Maximum & 10.3803 & 5.4031 & 4.4047 \\
Minimum & -11.1521 & -1.4100 & -0.5789 \\
Std. Dev. & 2.3206 & 1.1002 & 0.7745 \\
Skewness & -0.5683 & 0.6050 & 0.5436 \\
Kurtosis & 7.3579 & 3.6527 & 3.6613 \\
Jarque-Bera & $338.90[0.0000]^{* * *}$ & $31.59[0.0000]^{* * *}$ & $22.20[0.0000]^{* * *}$
\end{tabular}

Notes: Jarque-Bera (J-B) is the test statistic for the null hypothesis of normality in sample returns distribution. Significance levels: ${ }^{* * *} 1 \%,{ }^{* *} 5 \%,{ }^{*} 1 \%$.

Table 3. Summary statistics of change in US money supply.

\begin{tabular}{cccc}
\hline & M1 & M2 & M3 \\
\hline Mean & 0.4682 & 0.4905 & 0.5532 \\
Median & 0.4233 & 0.4763 & 0.5540 \\
Maximum & 5.9297 & 2.7625 & 2.0181 \\
Minimum & -3.2562 & -0.8031 & -0.4295 \\
Std. Dev. & 0.8353 & 0.3803 & 0.3767 \\
Skewness & 1.5996 & 1.4719 & 0.2463 \\
Kurtosis & 12.8138 & 9.6668 & 3.4505 \\
Jarque-Bera & $1780.23[0.0000]^{* * *}$ & $5.81[0.0546]^{*}$
\end{tabular}

Notes: Jarque-Bera (J-B) is the test statistic for the null hypothesis of normality in sample returns distribution. Significance levels: ${ }^{* * *} 1 \%,{ }^{* *} 5 \%$, ${ }^{*} 10 \%$.

and changes in the Korean money supply and the US money supply were positive. The kurtosis was positive for monthly stock returns and each money supply, and greater than 3. Returns skewness and each change in money supply skewness were positive, except the change in Korean money supply M1. Seasonally adjusted data were used to measure the money supply. Applying the Jarque-Bera (J-B) test for normality rejected the null hypothesis of normality for returns and money supply. 


\subsection{Unit Root Tests}

We tested the stationarity of returns and trading volume series, for which the most common test is the unit root test. To test for a unit root, we used both the augmented Dickey-Fuller (ADF) test and the Phillips-Perron (PP) test. Table 4 provides the results of these tests. The null hypothesis that returns and trading volume are non-stationary was rejected at the $1 \%$ significance level, indicating that both trading volume and returns were stationary. We did the same for returns and money supply, and obtained the same results, indicating that both returns and money supply were stationary (Table 4).

\subsection{Equations}

We used the GARCH model, proposed by Bollerslev [12]. However, one of its primary limitations is that it enforces a symmetric response of volatility to both positive and negative market shocks, because conditional variance is considered a function of the magnitude of lagged residuals, not whether they are positive or negative. However, a negative market shock may lead to more volatility than a positive shock of the same magnitude. To account for this, Nelson [13] developed the EGARCH model and Glosten, Jaganathan, and Runkle [14] introduced the GJR-GARCH model. In this study, we used both of these models to assess asymmetric volatility and the effect of new information arrival to the market. The GARCH $(1,1)$, GJR-GARCH $(1,1)$, and EGARCH $(1,1)$ models are defined as follows:

$$
\begin{gathered}
r_{t}=c_{1}+c_{2} r_{t}+\varepsilon_{t}, \\
h_{t}=\alpha+\beta \varepsilon_{t-1}^{2}+\gamma h_{t-1}, \\
h_{t}=\alpha+\beta \varepsilon_{t-1}^{2}+\delta d_{t-1} \varepsilon_{t-1}+\gamma h_{t-1}, \\
\ln \left(h_{t}\right)=\alpha+\beta\left(\frac{\varepsilon_{t-1}}{\sqrt{h_{t-1}}}\right)+\delta\left|\frac{\varepsilon_{t-1}}{\sqrt{h_{t-1}}}\right|+\gamma \ln \left(h_{t-1}\right) .
\end{gathered}
$$

where $r_{t}$ is the realized return of KOSPI and $c_{1}$ denotes the mean of the returns. Equation (4) is a conditional mean equation. It specifies the conditional variance as a function of mean volatility $\alpha$, where $\varepsilon_{t-1}^{2}$ is the lag in the squared residual of the mean (the ARCH term) and provides information about volatility clustering, and $h_{t-1}$ is the previously forecast variance (the GARCH term). In Equation (5), the term $\varepsilon_{t-1}^{2} d_{t-1}$ captures asymmetry, and $d_{t-1}$ is a dummy variable that is equal to 1 if $\varepsilon_{t-1}<0$ (bad news) and is equal to 0 if $\varepsilon_{t-1} \geq 0$ (good news). When $\varepsilon_{t-1}<0, d_{t-1}=1$, and the effect of an $\varepsilon_{t-1}$ shock on $h_{t}$ is $(\alpha+\beta) \varepsilon_{t-1}^{2}$. If $\delta>0$, negative shocks will have a larger effect on volatility than positive shocks. In Equation (6), the conditional variance is log-linear, which has several advantages over the pure GARCH specification. First, regardless of the magnitude of $\ln \left(h_{t}\right)$, the implied value of $h_{t}$ can never be negative, but the coefficients can be negative. Second, instead

Table 4. Results of unit root test for returns and money supply

\begin{tabular}{ccc}
\hline & ADF & PP \\
\hline Returns & $-17.4094[0.0000]^{* * *}$ & $-17.4007[0.0000]^{* * *}$ \\
Korean Money supply (M1) & $-19.3145[0.0000]^{* * * *}$ & $-19.4475[0.0000]^{* * *}$ \\
Korean Money supply (M2) & $-5.0643[0.0002]^{* * *}$ & $-23.9493[0.0000]^{* * *}$ \\
Korean Money supply (Lf) & $-4.1804[0.0053]^{* * *}$ & $-18.7636[0.0000]^{* * *}$ \\
US Money supply (M1) & $-4.4228[0.0022]^{* * *}$ & $-19.2469[0.0000]^{* * *}$ \\
US Money supply (M2) & $-5.9434[0.0000]^{* * *}$ & $-12.7542[0.0000]^{* * *}$ \\
US Money supply (M3) & $-2.3307[0.4156]$ & $-10.6707[0.0000]^{* * *}$
\end{tabular}

Note: The critical value for the ADF and PP tests are -3.9611 and -3.4323 at the $1 \%$ significance level, respectively. Significance levels: ${ }^{* * *} 1 \%$, ${ }^{* *} \%$, * $10 \%$; ADF, augmented Dickey-Fuller test; PP, Phillips-Perron test. 
of using $\varepsilon_{t-1}^{2}$, EGARCH uses a standardized value of $\frac{\varepsilon_{t-1}}{\sqrt{h_{t-1}}}$, which, third, allows asymmetry to be considered. Thus, the effect of shock on log conditional variance is $\alpha+\delta$ if $\frac{\varepsilon_{t-1}}{\sqrt{h_{t-1}}}$ is positive and $-\alpha+\delta$ if $\frac{\varepsilon_{t-1}}{\sqrt{h_{t-1}}}$ is negative.

To test the effects of money supply on the volatility of stock returns, the following models were used:

$$
\begin{gathered}
h_{t}=\alpha+\beta \varepsilon_{t-1}^{2}+\gamma h_{t-1}+\theta S_{t}, \\
h_{t}=\alpha+\beta \varepsilon_{t-1}^{2}+\delta d_{t-1} \varepsilon_{t-1}+\gamma h_{t-1}+\theta S_{t}, \\
\ln \left(h_{t}\right)=\alpha+\beta\left(\frac{\varepsilon_{t-1}}{\sqrt{h_{t-1}}}\right)+\delta\left|\frac{\varepsilon_{t-1}}{\sqrt{h_{t-1}}}\right|+\gamma \ln \left(h_{t-1}\right)+\theta S_{t} .
\end{gathered}
$$

If change in money supply is considered a proxy for information arrival, then it is expected that $\theta>0$. If change in money supply is serially correlated, $\beta$ and $\gamma$ will be small and statistically insignificant. The $\beta$ and $\gamma$ values are smaller when money supply is included than when it is excluded. All parameters of variance in Equations (3)-(9) can be estimated using the Brendt, Hall, Hall, and Hausman (BHHH) algorithm, assuming a general error distribution (GED) innovation.

\section{Empirical Results}

Table 5 presents the results when contemporaneous change in money supply is excluded. The GARCH term $(\gamma)$ is statistically significant at the $1 \%$ level in all models, whereas the ARCH term $(\beta)$ is significant in the GARCH and EGARCH models but not in GJR-GARCH. The returns exhibit high persistence in conditional variance. Note that the asymmetry term $(\delta)$ has the correct sign and is significant at the $1 \%$ level. These results imply that good news has a smaller effect on conditional volatility than bad news; that is, the market exhibits asymmetry.

Tables 6-11 present the results when contemporaneous change in money supply is included in the conditional variance equation. The coefficient of change in Korean money supply $\theta$ was statistically nonsignificant at the $10 \%$ level in all models. These results show that contemporaneous changes in Korean money supply did not explain volatility. The estimated coefficients of $\beta, \gamma$, and $\delta$ were highly significant but changes in the Korean money supply did not significantly reduce persistence.

Table 5. Results of models without money supply.

\begin{tabular}{cccc}
\hline & GARCH & GJR-GARCH & EGARCH \\
\hline$c_{1}$ & $0.8629(0.3262)^{* * *}$ & $0.7601(0.3307)^{* * *}$ & $0.7116(0.3357)^{* *}$ \\
$c_{2}$ & $0.1135(0.0535)^{* *}$ & $0.1093(0.0547)^{* * *}$ & $0.1361(0.0540)^{* *}$ \\
$\alpha$ & $2.4668(1.3537)^{*}$ & $3.2005(1.5880)^{* *}$ & $0.0533(0.1167)$ \\
$\beta$ & $0.1617(0.0583)^{* * *}$ & $0.0997(0.0643)$ & $0.3239(0.0922)^{* * *}$ \\
$\gamma$ & $0.7962(0.0665)^{* * *}$ & $0.7683(0.0787)^{* * *}$ & $0.9188(0.0358)^{* * *}$ \\
$\delta$ & & $0.1505(0.0915)^{*}$ & $-0.0947(0.0497)^{*}$ \\
$Q^{2}(24)$ & $23.113[0.454]$ & $23.900[0.409]$ & $26.353[0.284]$ \\
ARCH (10) & $1.1696[0.310]$ & $1.0715[0.383]$ & $1.2675[0.247]$
\end{tabular}

Note: Standard errors are in parentheses and p-values are in brackets. The Ljung-Box $Q_{2}(24)$ statistic tests serial correlations up to a $24^{\text {th }}$ lag length in the squared standardized returns. The ARCH (10) statistic tests the ARCH effects at $10^{\text {th }}$ order lagged, squared residuals. Significance levels: ${ }^{* * *} 1 \%$, ** $5 \%$, $10 \%$. 
Table 6. Results of models with contemporaneous Korean money supply (M1).

\begin{tabular}{cccc}
\hline & GARCH & GJR-GARCH & EGARCH \\
\hline$c_{1}$ & $0.8703(0.3250)^{* * *}$ & $0.7661(0.3290)^{* * *}$ & $0.6994(0.3346)^{* * *}$ \\
$c_{2}$ & $0.1148(0.0535)^{* *}$ & $0.1092(0.0547)^{* * *}$ & $0.1350(0.0542)^{* *}$ \\
$\alpha$ & $2.1368(1.3351)$ & $2.8596(1.5481)^{*}$ & $0.0488(0.1172)$ \\
$\beta$ & $0.1645(0.0594)^{* * *}$ & $0.0974(0.0653)$ & $0.3262(0.0932)^{* * *}$ \\
$\gamma$ & $0.7910(11.4342)^{* * *}$ & $0.7605(0.0814)^{* * *}$ & $0.9168(0.0368)^{* * *}$ \\
$\delta$ & & $0.1613(0.0941)^{*}$ & $-0.0986(0.0506)^{*}$ \\
$\theta$ & $0.3639(0.4364)$ & $0.4556(0.4242)$ & $0.0082(0.0145)$ \\
$Q^{2}(24)$ & $23.357[0.440]$ & $23.719[0.420]$ & $25.818[0.310]$ \\
ARCH (10) & $1.149[0.323]$ & $0.987[0.453]$ & $1.223[0.274]$
\end{tabular}

Note: See Table 5.

Table 7. Results of models with contemporaneous Korean money supply (M2).

\begin{tabular}{cccc}
\hline & GARCH & GJR-GARCH & EGARCH \\
\hline$c_{1}$ & $0.8741(0.3272)^{* * *}$ & $0.7607(0.3307)^{* *}$ & $0.7089(0.3383)^{* *}$ \\
$c_{2}$ & $0.1124(0.0537)^{* *}$ & $0.1060(0.0548)^{* *}$ & $0.1352(0.0542)^{* * *}$ \\
$\alpha$ & $1.6289(1.4686)$ & $1.7806(1.5119)$ & $0.0151(0.1133)$ \\
$\beta$ & $0.1604(0.0558)^{* * *}$ & $0.0878(0.0649)$ & $0.3139(0.0946)^{* * *}$ \\
$\gamma$ & $0.7983(0.0654)^{* * *}$ & $0.7736(0.0744)^{* * *}$ & $0.9221(0.0343)^{* * *}$ \\
$\delta$ & & $0.1671(0.0879)^{*}$ & $-0.0995(0.0486)^{* *}$ \\
$\theta$ & $0.5869(0.7046)$ & $1.0019(0.7786)$ & $0.0249(0.0222)$ \\
ARCH (10) & $22.781[0.474]$ & $22.652[0.481]$ & $24.797[0.361]$ \\
\hline
\end{tabular}

Note: See Table 5.

Table 8. Results of models with contemporaneous Korean money supply (Lf).

\begin{tabular}{cccc}
\hline & GARCH & GJR-GARCH & EGARCH \\
\hline$c_{1}$ & $1.0033(0.4039)^{* *}$ & $0.7815(0.4010)^{*}$ & $0.6478(0.4198)$ \\
$c_{2}$ & $0.1129(0.0601)^{*}$ & $0.1017(0.0611)^{*}$ & $0.1351(0.0588)^{* *}$ \\
$\alpha$ & $1.4231(1.9252)$ & $1.2187(1.7356)$ & $0.0735(0.1208)$ \\
$\beta$ & $0.1584(0.0665)^{* *}$ & $0.0468(0.0597)$ & $0.2741(0.0958)^{* * *}$ \\
$\gamma$ & $0.7724(0.8147)^{* * *}$ & $0.7673(0.0809)^{* * *}$ & $0.9147(0.0358)^{* * *}$ \\
$\delta$ & & $0.2294(0.0913)^{* *}$ & $-0.1587(0.0506)^{* * *}$ \\
$\theta$ & $2.4065(1.7847)$ & $2.8038(1.6046)^{*}$ & $0.0358(0.0307)$ \\
$Q^{2}(24)$ & $25.017[0.349]$ & $20.893[0.588]$ & $23.825[0.414]$ \\
ARCH (10) & $1.439[0.162]$ & $0.9399[0.496]$ & $1.2062[0.286]$ \\
\hline
\end{tabular}

Note: See Table 5. 
Table 9. Results of models with contemporaneous US money supply (M1).

\begin{tabular}{cccc}
\hline & GARCH & GJR-GARCH & EGARCH \\
\hline$c_{1}$ & $0.8629(0.3265)^{* * *}$ & $0.7589(0.3305)^{* * *}$ & $0.7341(0.3369)^{* * *}$ \\
$c_{2}$ & $0.1135(0.0536)^{* *}$ & $0.1093(0.0547)^{* * *}$ & $0.1359(0.0545)^{* *}$ \\
$\alpha$ & $2.4826(1.5498)$ & $3.1537(1.7729)^{*}$ & $0.0728(0.1287)$ \\
$\beta$ & $0.1616(0.0584)^{* * *}$ & $0.0998(0.0646)$ & $0.3201(0.0897)^{* * *}$ \\
$\gamma$ & $0.7962(0.0668)^{* * *}$ & $0.7685(0.0790)^{* * *}$ & $0.9173(0.0371)^{* * *}$ \\
$\delta$ & & $0.1509(0.0917)$ & $-0.0921(0.0501)^{*}$ \\
$\theta$ & $-0.0082(0.8775)$ & $0.0652(1.0374)$ & $-0.0242(0.0332)$ \\
$Q^{2}(24)$ & $23.114[0.454]$ & $23.878[0.411]$ & $25.654[0.317]$ \\
ARCH(10) & $1.169[0.310]$ & $1.070[0.384]$ & $1.249[0.257]$ \\
\hline
\end{tabular}

Note: See Table 5.

Table 10. Results of models with contemporaneous US money supply (M2).

\begin{tabular}{cccc}
\hline & GARCH & GJR-GARCH & EGARCH \\
\hline$c_{1}$ & $0.8758(0.3236)^{* * *}$ & $0.7717(0.3297)^{* *}$ & $0.7146(0.3348)^{* *}$ \\
$c_{2}$ & $0.1136(0.0536)^{* *}$ & $0.1096(0.0547)^{* * *}$ & $0.1357(0.0540)^{* * * *}$ \\
$\alpha$ & $1.4508(1.9144)$ & $2.1484(2.1945)$ & $0.0078(0.1348)$ \\
$\beta$ & $0.1656(0.0587)^{* * *}$ & $0.1016(0.0655)$ & $0.3294(0.0950)^{* * *}$ \\
$\gamma$ & $0.7987(0.0660)^{* * *}$ & $0.7737(0.0770)^{* * *}$ & $0.9202(0.0363)^{* * *}$ \\
$\delta$ & & $0.1481(0.0897)^{* *}$ & $-0.0945(0.049)^{*}$ \\
$\theta$ & $1.5809(2.3713)$ & $1.6235(2.7148)$ & $0.0716(0.0908)$ \\
$Q^{2}(24)$ & $22.776[0.474]$ & $23.539[0.430]$ & $25.962[0.303]$ \\
ARCH (10) & $1.168[0.311]$ & $1.052[0.399]$ & $1.224[0.273]$ \\
\hline
\end{tabular}

Note: See Table 5.

Table 11. Results of models with contemporaneous US money supply (M3).

\begin{tabular}{cccc}
\hline & GARCH & GJR-GARCH & EGARCH \\
\hline$c_{1}$ & $0.8815(0.3970)^{* *}$ & $0.7867(0.4071)^{*}$ & $0.7884(0.4067)^{*}$ \\
$c_{2}$ & $0.1309(0.0600)^{* * *}$ & $0.1262(0.0619)^{* *}$ & $0.1567(0.0618)^{* * *}$ \\
$\alpha$ & $1.9587(2.4112)$ & $2.3997(2.5660)$ & $-0.0226(0.1331)$ \\
$\beta$ & $0.1425(0.0564)^{* * *}$ & $0.0823(0.0641)$ & $0.3129(0.1016)^{* * *}$ \\
$\gamma$ & $0.8276(0.0644)^{* * *}$ & $0.8075(0.0786)^{* * *}$ & $0.9325(0.0370)^{* * *}$ \\
$\delta$ & & $0.1344(0.0929)$ & $-0.0863(0.0549)$ \\
$\theta$ & $0.1690(2.4208)$ & $0.6239(2.6037)$ & $0.0696(0.0713)$ \\
$Q^{2}(24)$ & $22.608[0.484]$ & $22.332[0.500]$ & $24.003[0.404]$ \\
ARCH (10) & $1.380[0.188]$ & $1.193[0.294]$ & $1.2777[0.242]$ \\
\hline
\end{tabular}

Note: See Table 5. 
Tables 9-11 show the same test for the US money supply. Like the change in Korean money supply, the coefficient of change in the US supply $\theta$ was nonsignificant at the $10 \%$ level in all models ${ }^{1}$. In addition, the estimated coefficients of $\beta, \gamma$, and $\delta$ were highly significant but changes in U.S. money supply did not significantly reduce persistence. Changes in the Korean and U.S. money supply did not affect Korean stock returns directly. The results based on a variance model indicated that the money supply of Korea and the U.S. had no effect. These formal studies suggest that past changes in money supply do not have significant forecasting power regarding market volatility. Moreover, it does not affect the asymmetric effects on returns. We evaluated the accuracy of each model specification using Ljung-Box $Q^{2}(24)$ and ARCH (10) tests, as shown in Tables 5-11. Neither test was significant at the $1 \%$ level, indicating that all models are sufficient for measuring the effects of information arrival on the market, when money supply is included.

\section{Summary}

We examined the relationships between changes in the money supplies of Korea and the United States and stock returns using the GARCH, GJR-GARCH, and EGARCH models. Our important findings are as follows. First, stock returns exhibited strong volatility, persistence, and asymmetry. Second, the inclusion of contemporaneous change variables on the Korean and US money supplies in all GARCH class models did not explain Korean stock return volatility. Third, an asymmetric effect of bad news on volatility existed when such contemporaneous changes were included in the volatility models. Changes in supply did not affect Korean stock returns directly. Finally, neither supply had any effect on the volatility of Korean stock returns. Although stock returns and volatility are not directly affected by changes in money supply, the influence of money supply on macroeconomic activity should not be ignored.

\section{Acknowledgements}

This work was supported by the National Research Foundation of Korea Grant funded by the Korean Government (NRF-2013S1A5B6053791).

\section{References}

[1] Pesando, J.E. (1974) The Supply of Money and Common Stock Prices: Further Observations on the Econometric Evidence. Journal of Finance, 29, 909-921. http://dx.doi.org/10.1111/j.1540-6261.1974.tb01490.x

[2] Keran, M.W. (1971) Expectation, Money and the Stock Market. Federal Reserve Bank of St. Louis Review, 53, $16-31$.

[3] Cassola, N. and Morana, C. (2004) Monetary Policy and the Stock Market in the Euro Area. Journal of Policy Modeling, 26, 387-399. http://dx.doi.org/10.1016/j.jpolmod.2004.03.012

[4] Homa, K.E. and Jaffee, D.M. (1971) The Supply of Money and Common Stock Prices. Journal of Finance, 26, 10441066. http://dx.doi.org/10.1111/j.1540-6261.1971.tb01747.x

[5] Hamburner, M.J. and Kochin, L.A. (1972) Money and Stock Prices: The Channels of Influences. Journal of Finance, 27, 231-249. http://dx.doi.org/10.2307/2978472

[6] Thorbecke, W. (1997) On Stock Market Returns and Monetary Policy. The Journal of Finance, 52, 635-654. http://dx.doi.org/10.1111/j.1540-6261.1997.tb04816.x

[7] Chen, S.S. (2007) Does Monetary Policy Have Asymmetric Effects on Stock Returns? Journal of Money, Credit and Banking, 39, 667-688. http://dx.doi.org/10.1111/j.0022-2879.2007.00040.x

[8] Kwon, C.S. and Shin, T.S. (1999) Cointergration and Causality between Macroeconomic Variables and Stock Market Returns. Global Finance Journal, 10, 71-81. http://dx.doi.org/10.1016/S1044-0283(99)00006-X

[9] Rozeff, M.S. (1974) Money and Stock Prices: Market Efficiency and the Lag in Effect of Monetary Policy. Journal of Financial Economics, 1, 245-302. http://dx.doi.org/10.1016/0304-405X(74)90020-8

[10] Rogalski, R.J. and Vinso, J.D. (1977) Stock Returns, Money Supply and the Direction of Causality. The Journal of Finance, 32, 1017-1030. http://dx.doi.org/10.1111/j.1540-6261.1977.tb03306.x

[11] Alatiqi, S. and Fazel, S. (2008) Can Money Supply Predict Stock Prices? Journal for Economic Educators, 8, 54-59.

[12] Bollerslev, T. (1986) Generalized Autoregressive Conditional Heteroskedasticity. Journal of Econometric, 31, 307-327. http://dx.doi.org/10.1016/0304-4076(86)90063-1

[13] Nelson, D.B. (1991) Conditional Heteroskedasticity in Asset Returns: A New Approach. Econometrica, 59, 323-370.

${ }^{1}$ Lagged variable of change in money supply does not affect stock returns volatility. 
http://dx.doi.org/10.2307/2938260

[14] Glosten, L.R., Jaganathan, R. and Runkle, D.E. (1993) On the Relation between expected Value and the Volatility of the Nominal Excess Return on Stocks. The Journal of Finance, 48, 1779-1801.

http://dx.doi.org/10.1111/j.1540-6261.1993.tb05128.x 